JEL M21, N80, O10

\title{
ОСНОВИ РОЗВИТКУ МАЛОГО БІЗНЕСУ В УКРАЇНІ
}

\author{
Ю. Максимець, А. Ілечко, В. Дмитрук \\ Львівський національний університет імені Івана Франка \\ 79008, м. Львів, проспект Свободи, 18 \\ e-mail:maxymezj@gmail.com; ilechko25@gmail.com,pik_viktoria@ukr.net \\ Досліджено основи розвитку малого бізнесу в Україні. Вивчено досвід \\ зарубіжних країн у підтримиі малого бізнесу. Наведенно приклади \\ підтримки малого бізнесу у світі. Виділено тендениії міжнародного \\ досвіду підтримки розвитку малого бізнесу. Результатом проведеного \\ дослідження є визначення заходів, які Україна повинна здійснити, для \\ зростання малого бізнесу.
}

Ключові слова: малий бізнес, розвиток малого бізнесу, підтримка малого бізнесу, стимулювання малого бізнесу, програми підтримки.

Малий бізнес є невід'ємною частиною функціонування конкурентної ринкової системи господарювання, саме тому його розвиток відіграє важливу роль в економіці будь якої країни. Малий бізнес створює нові робочі місця, підвищує добробут населення та забезпечує економічне зростання країни.

Малий бізнес $\epsilon$ дуже важливий для економіки кожної держави. Дрібні підприємці багато вносять до державного бюджету. Можна сказати, що комплекс малих та середніх фірм забезпечує країні такий же прибуток, як і великий бізнес. Простими словами, процвітаюча держава не може вижити без малого бізнесу.

Метою статті $\epsilon$ визначення заходів на шляху підтримки розвитку малого бізнесу в Україні.

Відповідно до мети сформульовано такі завдання: дослідити досвід зарубіжних країн у підтримці малого бізнесу; визначити заходи необхідних для зростання малого бізнесу в України.

Підтримка малого бізнесу є актуальною як для України, так і для розвинених країн. Це знаходить своє відображення на офіційних веб-сайтів інституцій, які цим займаються (наприклад, $[1 ; 2])$. Ускладнення проблем, пов'язаних із забезпеченням сталого економічного зростання та конкурентоспроможності, породжує збільшення інтересу до малого бізнесу в останні роки, про що зазначають Ф. Файоль і А. Тоун. В роботах вітчизняних дослідників піднімається питання підтримки малого бізнесу. У своїй роботі I. Манцурова (зі співавторами) досліджує проблеми розвитку сектора малого бізнесу та результати діяльності малих підприємств в Україні [3]. Це обгрунтовує необхідність підтримки розвитку малого бізнесу. Дослідження Р. Пустовійта вказують на необхідність приділити увагу формуванню та вдосконаленню інституційного середовища підприємництва [4].

Малий бізнес є найдинамічнішою, масовою та гнучкою формою ділового життя та $є$ основою країни. Значимість малого бізнесу визначається тим, що чисельність

(C) Ю. Максимець, А. Ілечко, В. Дмитрук, 2019 
малих підприємств та працівників, які працюють на них $є$ однією 3 найбільш суттєвих якісних характеристик будь-якої країни 3 розвиненою ринковою економікою.

Розвинуті країни, визнаючи та розуміючи важливість малого бізнесу, різноманітними методами та шляхами сприяють його розвитку.

Чимало країн створили відомства, діяльність яких спрямована саме на підтримку суб’єктів малого бізнесу. Так, в 1953 році Конгресом Сполучених Штатів Америки створено Адміністрацію по справах малого бізнесу (U.S. Small Business Administration - SBA), яка і досі захищає інтереси суб'єктів малого підприємництва на державному рівні. Серед основних завдань діяльності Адміністрації щодо суб'єктів малого бізнесу:

- технічна та інформаційна підтримка;

- допомога в отриманні кредитів, надання кредитних гарантій;

- сприяння в отриманні державних замовлень та отриманні контрактів 3 великими підприємствами;

- безпосереднє субсидування та кредитування малого бізнесу за рахунок коштів власного бюджету [5].

Державним органом 3 регулювання здійснення діяльності підприємств малого бізнесу Японії є Управління малих підприємств, що підпорядковане Міністерству зовнішньої торгівлі і промисловості. Управління малих підприємств займається контролем виконання антимонопольного законодавства, забезпеченням державного захисту інтересів малого підприємництва країни, обмеженням контролю власників бізнесу, визначенням відповідальності замовників і виконавців при укладенні між ними договірних угод.

Основним державним органом підтримки малих підприємств в Китаї є спеціалізоване агентство - Китайський центр по координації і кооперації бізнесу. Основне завдання центру - створення необхідної інфраструктури для технологічного співробітництва між національними та зарубіжними організаціями в сфері підтримки підприємництва.

Для розвинутих країн органи підтримки малого підприємства виконують функцію навчання ведення бізнесу, також вони надають інформацію підприємствам та допомогу в отриманні пільгових кредитів тощо.

Розвиток малого бізнесу в Україні не можливий без підтримки різних інституцій. Особливе місце у даному питанні відіграє кредитування суб'єктів малого бізнесу. На даний час в нашій державі малим підприємствам, якщо і вдається взяти кредит в банку, то відсотки за нього є неймовірно високими -15-30\% річних. У багатьох країнах, держава дбаючи про розвиток малого бізнесу, впроваджує різноманітні програми, які дають можливість малому бізнесу брати кредити від 2 \% річних.

Так, Німеччина запустила 200 програм підтримки малого бізнесу під загальною назвою Mittelstand, які передбачають виділення на кредитування таких підприємств 15,5 млрд євро щорічно [6].

У Британії для підтримки малого бізнесу діє Схема забезпечення кредитів малим підприємствам, по якій малі підприємства 3 доходом до 5,6 млн фунтів можуть отримати кредит 250000 фунтів на термін до 5 років під $2 \%$ річних [7].

У багатьох країнах світу державою були проведені реформи на зниження адміністративного навантаження i спрощення процедури створення нових підприємств. Багато країн спростили процедуру видачі дозволів на будівництво, реєстрацію майна і зовнішньоторговельні операції. Зміни в законодавстві, що 
стосуються зменшення видів діяльності, які повинні ліцензуватися, спрощення процедур отримання ліцензій і сертифікатів, скорочення числа інстанцій, які повинні видавати дозволи при відкритті нових підприємств, і перевірок з боку контролюючих органів проводяться як в розвинених країнах, так і в країнах, що розвиваються.

Розвиток малого бізнесу в Україні можливий лише після проведення ряду реформ в країні. Ухвалення законів - це один із етапів реформ. Проте реалізація законів має безліч перешкод і тому вивчаючи досвід інших країн, в нас є можливість підготувати умови, при яких реформи будуть проходити найбільш успішно.

Для України позитивним є досвід Польщі у впровадженні інституційних реформ.

Удосконалення інституційного забезпечення підприємницької діяльності дало змогу країні піднятися в рейтингу Doing Business з 74 у 2011 р. на 25 місце у 2016 p. [8].

Розглядаючи міжнародний досвід підтримки розвитку малого бізнесу можна виділити такі тенденції:

1) Уряди більшості країн світу підтримують розвиток малого бізнесу численними державними програмами, вартість яких сягає мільярдів доларів.

2) Сприяння експорту та інформаційна підтримка малого бізнесу є основними інструментами, які стимулюють розвиток малого бізнесу.

3) Законодавство у більшості країн спрямована на зниження правового регулювання діяльності малих підприємств, зменшення адміністративних бар'єрів.

4) Цілями програм підтримки малого бізнесу є створення нових підприємств та робочих місць, підтримка інновацій і використання нових технологій.

В Україні ж і досі не сформована інфраструктура підтримки і розвитку малого бізнесу. Про це свідчать результати експертного опитування Центру громадської експертизи. Зокрема лише 43 \% респондентів вважають, що органом, відповідальним за формування і реалізацію політики підтримки малого бізнесу в Україні, має бути Міністерство економічного розвитку і торгівлі. За результатами опитування учасників конференції "Ефективний діалог заради розвитку: політика влади і порядок денний для бізнесу”, що відбулася 23 червня 2016 року, найбільш затребуваною складовою системою підтримки підприємництва в Україні $є$ фінансово-кредитна підтримка (78 \%), а також стимулювання інновацій і підтримка експорту (по 65 \% опитаних). Найбільшими перепонами для розвитку бізнесу сьогодні $\epsilon$ корупція (65\%), обмежений доступ до фінансових ресурсів (57\%) і надмірний податковий тиск $(54 \%)$ [8].

Зарегульованість економіки (22\%) й адміністративний тиск на підприємства (19\%), на думку експертів, є менш болючими для бізнесу. В цілому ж за даними малий та середній бізнес оцінює довгострокові перспективи змін у бізнес-кліматі досить позитивно: 53 \% підприємців планують активізувати свою бізнес діяльність. I це незважаючи на те, що малі й середні підприємства в Україні у середньому близько 30 \% прибутку витрачають, аби вести бізнес легально: на ліцензії, сертифікати, перевірки, дозволи тощо [8].

Зважаючи на складну економічну ситуацію в Україні, активізація розвитку малого бізнесу $\epsilon$ актуальним питанням. Саме цей сектор економіки $\epsilon$ доволі мобільним, швидко реагує на зміни кон’юнктури ринку, здатний вирішувати найгостріші соціальні й економічні проблеми (наприклад, створення додаткових робочих місць), є вагомим джерелом наповнення бюджетів різних рівнів, підвищує добробут населення, формує конкурентне середовище, збільшує кількість інвестицій в економіку [9, с. 9]. 
Важливим чинником, який гальмує розвиток малого бізнесу в країні є рівень корупції.

Згідно із рейтингом, складеним неурядовою міжнародною організацією Transparency International: The Corruption Perceptions Index 2015, за рівнем корупції Україна займає 130 місце (з 167 країн). Надмірно високим є рівень корупції в Греції та Італії, що негативно позначається на інституційному забезпеченні розвитку підприємництва: Греція - 58, Італія - 61 [10]. Показник “свобода від корупції”, що $є$ однією із складових індексу економічної свободи, в Україні становить 23, в Італії 39, Данії - 94 [10]. Меншим є рівень корупції в Чехії, Угорщині, Словаччині, Румунії та ін. Найменш корумпованою країною в $€ \mathrm{C} €$ Данія. Основними напрямами подолання корупції в $Є С$ є: сприяння розвитку громадянського суспільства та забезпечення можливостей для здійснення моніторингу управління й боротьби 3 корупцією (Румунія, Португалія, Греція, Словаччина та ін.); проведення аудиту державних витрат і бюджетного планування, контроль над прозорістю відносин власності та широким висвітленням у ЗМІ процесів приватизації; зростання судової автономії та підзвітності (Румунія, Італія, Греція та ін.).

Висновки. Отже, на даний час, в Україні існує потреба у пошуку нових підходів розв'язання накопичених проблем у малому бізнесі. Для цього потрібно здійснити такі реформи та заходи:

1. Визначити напрями, які $\epsilon$ пріоритетними для фінансування у малому бізнесі. При цьому, слід виходити результатів аналізу статистичних даних, що свідчать про найширший розвиток малого бізнесу у цих сферах, як в Україні, так і в усьому світі.

2. Розробити державну систему підтримки малого бізнесу.

3. Визначити економічні та соціальні проблеми в частині підтримки і розвитку малого бізнесу на районному та регіональному рівнях, з урахуванням того, що діяльність малого бізнесу орієнтована, головним чином, на місцевий ринок.

4. Систематизувати базу даних, яка інформуватиме про використання коштів, спрямованих на підтримку бізнесу в Україні, з подальшим аналізом ефективності їх використання.

Дані заходи дадуть можливість залучити нові фінансові ресурси, а також забезпечать прибутковість цих ресурсів, що дасть потужний розвиток малого бізнесу в країні.

1. Small Business Administration (SBA): official site [Electronic resource]. - Access mode: http://www.sba.gov/.

2. Outline of Japan's SME policies [Electronic resource]. - Access mode: http://www.sme.ne.jp

3. Розвиток малих підприємств (статистичне оцінювання впливу на економічне зростання та конкурентоспроможність країни) : [монографія] / [І. Г. Манцуров, С. С. Ващаєв, С. Г. Дрига та ін. ; за наук. ред. І. Г. Манцурова]. - К.: КНЕУ, 2009. $-181 \mathrm{c}$.

4. Пустовійт Р. Ф. Формування інституційного середовища підприємництва в трансформаційній економіці : автореф. дис. на здобуття наук. ступеня доктора екон. наук. : спец. 08.01.01 - економічна теорія / Р. Ф. Пустовійт ; НАН України, Держ. уст-ва “ІЕП НАН України". -К., 2006. - 36 с.

5. Ольвінська Ю.О . Особливості державного регулювання малого підприємництва у країнах світу [Електронний ресурс] / Ю. О. Ольвінська // Державне управління: удосконалення та розвиток. - 2015. - №2. - Режим доступу: http://www.dy.nayka.com.ua/?op=1\&z=814 
6. Букатюк У. Підтримати малий бізнес. Як Україна відстала від світу [Електронний ресурс ] / У. Букатюк // Еспресо. - 11.07.2017. - Режим доступу: https://espreso.tv/article/2017/07/11/malyy_seredniy_biznes

7. Міняйло Н. Гроші на бізнес від держави. В розвинених країнах уряди дають дешеві кредити малим підприємствам [Електронний ресурс] / Н. Міняйло. - Режим доступу: http://texty.org.ua/pg/article/editorial/read/77577/Groshi_na_biznes_vid_derzhavy_V_rozvynenyh

8. Doing Business 2016: Doing Business in a More Transparent World. - Washington : Published by IFC. -2015 . -199 p.

9. Doing Business 2016: Doing Business in a More Transparent World. - Washington : Published by IFC. -2015 . - 199 p.

10. Пивоваров М. Розвиток інституту інфраструктури малого підприємництва: проблеми та шляхи його покращення / М. Пивоваров // Соціально-економічні проблеми і держава. - 2013. - Вип. 1 (8). - С. 6-18.

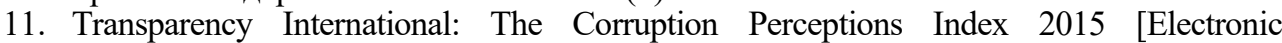
resource]. - Access mode: http://gtmarket.ru/ratings/corruption-perceptions-index/info.

\section{References}

1. Ofitsiinyi veb-sait Administratsii maloho biznesu SShA [The official website of the US Small Business Administration]. sba.gov. Retrived from http:/ /www.sba.gov/.

2. Outline of Japans SME policies. sme.ne.jp. Retrived from http://www.sme.ne.jp

3. Mantsurova, I. H. (Eds.). (2009). Rozvytok malykh pidpryiemstv (statystychne otsiniuvannia vplyvu na ekonomichne zrostannia ta konkurentospromozhnist krainy) [Small business development (statistical assessment of the impact on economic growth and competitiveness of the country)]. K. : KNEU [in Ukrainian].

4. Pustoviit, R. F. (2006) Formuvannia instytutsiinoho seredovyshcha pidpryiemnytstva v transformatsiinii ekonomitsi [Forming the institutional environment of entrepreneurship in a transformational economy]. Extended adstract of Doctor's thesis. K.: NAN Ukrainy, Derzh. ust-va "IEP NAN Ukrainy" [in Ukrainian].

5. Olvinska, Yu. O. (2015). Osoblyvosti derzhavnoho rehuliuvannia maloho pidpryiemnytstva u krainakh svitu [Features of state regulation of small business in the countries of the world]. Derzhavne upravlinnia: udoskonalennia ta rozvytok - Public Administration: Improvement and Development, 2. www.dy.nayka.com.ua. Retrived from http://www.dy.nayka.com.ua/?op=1\&z=814 [in Ukrainian].

6. Bukatiuk, U. (2017). Pidtrymaty malyi biznes. Yak Ukraina vidstala vid svitu [Support small business. How Ukraine lagged behind the world]. Espreso - Espreso, 11.07. espreso.tv. Retrived from https://espreso.tv/article/2017/07/11/malyy_seredniy_biznes [in Ukrainian].

7. Miniailo, N. Hroshi na biznes vid derzhavy. V rozvynenykh krainakh uriady daiut deshevi kredyty malym pidpryiemstvam [Money for business from the state. In developed countries, governments provide cheap loans to small businesses]. texty.org.ua. Retrived from http://texty.org.ua/pg/article/editorial/read/77577/Groshi_na_biznes_vid_derzhavy_V_rozvynenyh [in Ukrainian].

8. Doing Business 2016: Doing Business in a More Transparent World (2015). Washington : Published by IFC.

9. Pyvovarov, M. (2013). Rozvytok instytutu infrastruktury maloho pidpryiemnytstva: problemy ta shliakhy yoho pokrashchennia [Development of the Small Business Infrastructure Institute: Challenges and Ways to Improve it]. Sotsialno-ekonomichni problemy $i$ derzhava - Socio-economic problems and the state, 1 (8), 6-18 [in Ukrainian].

10. Transparency International: The Corruption Perceptions Index 2015. (2015). gtmarket.ru. Retrived from http://gtmarket.ru/ratings/corruption-perceptionsindex/info. 
FUNDAMENTALS OF SMALL BUSINESS DEVELOPMENT IN UKRAINE

\title{
Yu. Maksymets, A. Ilechko, V. Dmytruk
}

\author{
Ivan Franko National University of Lviv \\ 79008, Lviv, Svoboda Avenue, 18 \\ e-mail:maxymezj@gmail.com; ilechko25@gmail.com,pik_viktoria@ukr.net
}

The article is devoted to the research of the main development of small business in Ukraine. Small business is well known for the economics it deals with, it does not confirm the share of the functioning of a competitive market economy system, and then it tried to play in the economy of any country. Small business produces a large number of new jobs and it stimulates the country's economy.

In a scientific study, truly polluted countries with small business support were investigated. For example, in 1953, the United States Congress created the Office of Small Business (American Small Business Administration - SBA), which protects interested businesses involved in public business.

The governing body of small business in Japan is the management of small businesses. The main state body of major enterprises in China is a specialized agency, the China Center for Coordination and Cooperation.

In addition, our scientific service has used small businesses in the world. So, Germany allowed to receive 200 small business programs under the general permission of Mittelstand, and Britain for small business preparation a scheme of loans for enterprises.

We also looked at trends in international small business development experience.

For the results of the research work on the need for a series of reforms to develop small businesses in Ukraine. Positive Assassination prepared for this reform, which played out all the time in foreign countries that could move to small business at a new level.

In addition, we understand what we consider to be a factor that has a higher level of corruption.

In its trusted section, a country that has an excessively high level of corruption, as well as those in corruption, is low.

In addition, the result of the study is the use that Ukraine has to make for other small businesses, namely: to find pressure that is a priority for planning in the European environment; expand the retained small business system; should see the economic and social problems in the development and development of small businesses.

Keywords: small business, small business, supporting small business, stimulating small business, programming. 